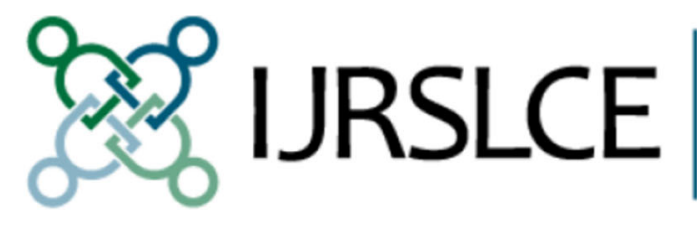

\author{
International Journal \\ for Research on \\ Service-Learning \& \\ Community Engagement
}

\title{
Mid-Career Faculty and High Levels of Community Engagement: Intentional Reshaping of Meaningful Careers
}

\author{
Anne M. DeFelippo \\ Dwight E. Giles, Jr.
}

This article was originally published at:

https://journals.sfu.ca/iarslce/index.php/journal/article/view/133/80

Recommended Citation

DeFelippo, A. M., \& Giles, D. E., Jr. (2015). Mid-career faculty and high levels of community engagement: Intentional reshaping of meaningful careers. International Journal of Research on Service-Learning and Community Engagement, 3(1), Article 11. 


\title{
Mid-Career Faculty and High Levels of Community Engagement: Intentional Reshaping of Meaningful Careers
}

\author{
Anne M. DeFelippo \\ Salem State University \\ Dwight E. Giles, Jr. \\ University of Massachusetts, Boston
}

\begin{abstract}
This study examined the relationship between vital mid-career faculty and rates of participation in community engagement at three public comprehensive universities in New England. Specifically, midcareer faculty successfully taught, rendered service within their setting, and conducted some research, but in interviews they described additional meaning and career fulfillment derived from creating and maintaining niches of community engagement focusing on social problems and change. Data from 102 faculty surveys were analyzed in the form of descriptive statistics, correlations, and t-tests. Data from 30 face-to-face interviews with faculty - all of whom were selected for their high self-vitality ratings as well as gender, rank, and discipline-were coded and assigned themes. There appeared to be a positive correlation between mid-career faculty who chose to participate in community engagement and high levels of vitality that may be influenced and enhanced by the engagement itself.
\end{abstract}

Keywords: community engagement, mid-career faculty, faculty vitality, service-learning

The practice of community engagement is flourishing at many higher education institutions. One of the reasons community engagement is consistently popular is due to its positive impact on student learning outcomes and on student growth and development (Bringle \& Hatcher, 2009; Cooper, 2000; Stanton, Giles, \& Cruz, 1999; Strait \& Lima, 2009). It has been shown that an important goal of community engagement at the university undergraduate level is to create more civic-minded citizens who are aware of social issues and the need for change (Astin \& Vogelgesang, 2006; Eyler \& Giles, 1999; Steinberg, Hatcher, \& Bringle, 2011; Ward, 2010). Literature is emerging about the movement of colleges and universities toward acquiring the Carnegie Foundation's classification for community-engaged institutions ("Carnegie Community Engagement Classification," 2015; Giles, Sandmann \& Saltmarsh, 2010; Noel \& Earwicker, 2014; Ward, Buglione, Giles, \& Saltmarsh, 2011). Exemplars have been cited for their work focusing on civic and social causes (O'Meara \& Niehaus, 2009), and awards have been named in honor of pioneer faculty who personified this work, including the Thomas P. Ehrlich Award and the Ernest A. Lynton Award (O’Meara, 2008).

Scholars have made the case for institutions to reward faculty for their participation in community engagement (O'Meara \& Rice, 2005). However, few colleges and universities base tenure, promotion, or post-tenure review outcomes on community engagement (Saltmarsh, Giles, O'Meara, Sandman, Ward, \& Buglione, 2009; Saltmarsh, Giles, Ward, \& Buglione, 2009), though some faculty is intrinsically motivated to include a community engagement piece in their courses. The National Campus Compact, which counts about one third of U.S. colleges as members, reported in its 2012 member survey that 
campuses offered an average of 66 service-learning courses per campus and that approximately $7 \%$ of faculty taught service-learning courses, with $95 \%$ of member campuses offering such courses (Campus Compact, 2013). O'Meara (2008) described a variety of factors that motivate faculty to participate in community engagement. At this time, however, there are surprisingly few descriptions in the literature of the impact of community engagement on faculty themselves.

One purpose of this study was to add to the knowledge about vital mid-career faculty and their work in public comprehensive universities. A second purpose was to operationalize faculty vitality in order to identify a formative framework that includes the exploration of faculty community engagement, faculty motivation to pursue service-learning as part of changing roles, and the impact of community engagement on faculty. Three research questions guided this study:

(1) To what extent do vital mid-career faculty participate in community engagement?

(2) What are the motivational factors for faculty pursuing community engagement?

(3) Is there a relationship between faculty vitality, productivity, and community engagement?

\section{Mid-Career Faculty}

While some stakeholders think that many tenured faculty are stale and lack professional motivation (Licata \& Morreale, 2006; Sykes, 1988), this perception is inaccurate. The largest group of tenured faculty in the United States comprises those at the mid-career stage, and they produce the most published articles, teach more students, and conduct more consulting than faculty at any other career stage (Baldwin $\&$ Chang, 2000). Mid-career faculty have mastered teaching and are often seeking more meaningful work outside of the classroom - projects that make a positive difference in the lives of persons in need.

Some faculty appears to have what Ward (2010) described as a twofold agenda-one for the university and one for themselves. As activist professionals (Hart, 2008), some vital mid-career faculty help to shape their institutions and often share the same values and missions as their universities, including service to the community and addressing issues involving equity and social well-being (O’Meara, Sandmann, Saltmarsh, \& Giles, 2011). Mid-career faculty seems to create niches or projects outside of the classroom in which they take a deep professional interest (Baldwin \& Blackburn, 1981). Levine (2000) described how service-learning is a vehicle for "social and economic justice" (p. xii). Similarly, Cooper (2000), at mid-career, discovered he possessed a strong "capacity for connectedness" (p. 151), and he asked himself, "How could I be of service?" (p. 153).

\section{Faculty Vitality}

This study defined faculty vitality as the constellation of attitudinal dispositions and psychological states (DeFelippo, 2014). These dispositions include balance, challenge seeking, creativity, curiosity, energy, grit, growth mindset, motivation, optimism, and risk taking. These are not considered personality traits, which are often permanent; dispositions may increase or decrease over time. For this reason, they are considered to be attitudinal dispositions and psychological states of being. These dispositions and states are present and at higher levels in vital mid-career faculty (DeFelippo, 2014). An important part of vitality is productivity, which was measured during the study by accounting for faculty members' professional memberships, conference attendance, presentations, journal articles, chapters, books, grants, and community engagement experiences over a two-year period (DeFelippo, 2014). 


\section{Community Engagement}

While the term service-learning has been in use for decades, it has been used more recently as part of the larger concept of community engagement, which includes service-learning, community-based research, and action research, and refers both to students and faculty (Giles, 2008). Bringle and Hatcher (2009) and Cooper (2000) agree that student learning, personal and professional development, and social awareness are enhanced through service-learning. Research around how service-learning relates to faculty work is emerging at this time; the first issue of the Michigan Journal for Community Service-Learning in 1994 contained four articles on faculty and service-learning. The growing evidence suggests that servicelearning may represent an opportunity structure that universities could promote to simultaneously enhance professional growth of faculty and student learning (O'Meara \& Niehaus, 2009). Service-learning may promote "healing and transforming of life," and some scholars view service-learning as spiritual (Chambers \& Chambers, 2000, p. xiii). O'Meara (2008) defined faculty community engagement as "work that engages a faculty member's professional expertise to solve real world problems that fulfill institutional mission and are public, not proprietary" (p. 8). Key research about faculty involvement in service-learning has shown that service-learning is viewed primarily as a way to enhance teaching and learning (O’Meara \& Niehaus, 2009).

\section{Partnerships}

The Carnegie Foundation for the Advancement of Teaching, through its Elective Community Engagement Classification, defines community engagement as:

collaboration between institutions of higher education and their larger communities (local, regional/state, national, global) for the mutually beneficial exchange of knowledge and resources in a context of partnership and reciprocity.

The purpose of community engagement is the partnership of college and university knowledge and resources with those of the public and private sectors to enrich scholarship, research, and creative activity; enhance curriculum, teaching and learning; prepare educated, engaged citizens; strengthen democratic values and civic responsibility, address critical societal issues, and contribute to the public good (“Carnegie," 2015).

Cooper (2000) described "close partnerships ... extending far beyond my department" (p. 154) into "hearing chambers, neighborhood centers, and professional offices" (p. 155).

\section{Theoretical Framework}

This study drew on O'Meara's (2008) research on exemplary faculty who engage in innovative servicelearning and high-impact scholarship in order to frame our qualitative findings. These exemplars demonstrated effective leadership in community engagement to the extent that they won the prestigious Thomas P. Ehrlich Faculty Award for Service-Learning (http://www.compact.org/initiatives/awardsprograms/the-thomas-ehrlich-civically-engaged-faculty-award/). O'Meara found seven motivational factors that explain why faculty engage in service-learning: (1) "Motivation to facilitate student learning and growth," that is, faculty wish for students to better understand course material and to learn and grow from the community engagement experience. (2) "Motivation grounded in the perceived fit between discipline and engagement," which relates to vital mid-career faculty perceptions of the relationship to the university. Faculty have "continuous reciprocal interactions" with their institutions (O'Meara, Terosky, \& Neumann, 2008, p. 24). When fit is good, faculty tend to remain at their universities (Lindholm, 2003). (3) "Motivation grounded in personal commitments to specific social issues, people, and places." Faculty examine ideals that people intentionally hold and model their lives by, including the principle of equity, the notion that education must be accessible to all in a democracy, and the belief that education should serve others. (4) "Motivation grounded in personal/professional identity." This refers to faculty who value and pride themselves on how they have evolved into who they are now. They easily identify with 
persons from similar socioeconomic or cultural backgrounds (Blackburn \& Lawrence, 1995). (5) "Motivation grounded in a pursuit of rigorous scholarship and learning." The faculty member is driven by a research agenda that integrates the responsibilities of faculty teaching, rendering service, and publishing articles. (6) "Motivation grounded in a desire for collaborative relationships, partners, and public making," which describes the influence of colleagues with expertise in this area in helping to guide others to experience community engagement. Moreover, working with a community partner as an equal is a critical component of successful engagement. (7) "Motivation as grounded in institutional type and mission, appointment type, and/or an enabling reward system and culture or community engagement," that is, some faculty have been socialized into a culture that expects and encourages community engagement because of its underlying values, mission, and goals. Often faculty may find their goals, beliefs, and values are congruent with those of the university (O'Meara, 2008, pp. 14-22).

\section{Research Design}

The purpose of this mixed-methods sequential exploratory study was to identify vital mid-career faculty, examine their motivations for participating in community engagement, and determine if there was a relationship between faculty vitality and community engagement (Plano Clark \& Creswell, 2008). The two-step sequence involved a questionnaire (also referred to in this article as a survey) followed by interviews with selected participants to explore their questionnaire responses. We focused primarily on the qualitative data of our study, giving particular attention to 12 of the 30 faculty interviews, in which motivational factors were discussed. Secondarily, we studied the quantitative data from 102 faculty questionnaires, whose respondents self-rated vitality and from which the 30 faculty with the highest vitality scores were selected for interviews. See Table 1 for a summary of participant selection.

Table 1. Summary of Methodology for Selection of Faculty Participants

300 mid-career faculty sent online survey

102 mid-career faculty responded to survey

30 mid-career faculty were interviewed based on high self-rated vitality scores

$\mathbf{1 5}$ full professors, $\mathbf{1 5}$ associate professors

15 women, 15 men

A variety of disciplines

26 of 30 interviewees responded that they participated in community engagement

12 of 26 faculty discussed community engagement in face-to-face interviews

\section{Sites}

We chose three New England public comprehensive universities for this study after meeting with two higher education experts who assessed these sites as being vitality-supporting, meaning that the administration publicly acknowledged and valued faculty and provided professional development for mid-career faculty. The three sites were assigned pseudonyms: Exemplary University, Rockland University, and Synergy State. Little has been written about public comprehensive universities, and faculty who work there are rarely studied (Henderson, 1995; Tierney, 2008). Most research on faculty has been quantitative and has focused on Research I institutions. "The state comprehensive universities may represent the most neglected and least understood segment of American higher education" 
(Henderson, 2009, p. 1). Public comprehensive universities are known for heavy teaching workloads, and the students in these settings usually work off campus and are often first-generation, nontraditional, career-oriented commuters (Dalbey, 1995).

\section{Participant Selection for Questionnaire Completion}

Associate professors' names and full professors' names at each site were listed alpha numerically and randomly ordered (using Random.org). The first 100 randomly selected faculty at each site were sent (via email) invitations to participate in the study, information about the study, and consent forms. The questionnaire completion rate was 29\% (29 faculty) for Exemplary University, 36\% (36 faculty) for Rockland University, and 37\% (37 faculty) for Synergy State, for a total of 102 faculty. Thus, the sample size of our quantitative data was 102 .

We purposively selected 30 faculty-10 from each of the three sites - to participate in face-to-face, audio-recorded interviews that were then transcribed, analyzed, and coded using the data-analysis software NVivio to create and cluster themes that would comprise the study findings. Of the study's 30 interviewees (all of whom were given pseudonyms), 15 were full professors and 15 were associate professors, and they included 15 men and 15 women. Four interviewees were international faculty, and two were faculty of color. Female professors reported their vitality scores between 78 and 107 points, while male professors rated their vitality scores between 78 and 94 . One hundred and seven points (out of a possible 128) represented the highest self-rated vitality score in the study. See Table 2 for the 30 interviewees' scores. A number of variables were used in the selection process including high vitality scores, rank, gender, discipline, and availability to participate in an interview. The selection process provided a balanced group of mid-career interview participants.

Table 2. Summary of Demographic Information for the 30 Faculty Interviewees

\begin{tabular}{|c|c|c|c|c|c|}
\hline Pseudonym & Gender & Score & Institution & Rank & Discipline \\
\hline Homeaway & Female & 107 & Exemplary & Full & Education \\
\hline Visor & Female & 106 & Rockland & Full & Education \\
\hline Heartsoul & Female & 94 & Exemplary & Associate & Education \\
\hline Mentored & Male & 94 & Synergy & Associate & Mathematics \\
\hline Star & Female & 92 & Synergy & Associate & Science \\
\hline Confluence & Female & 92 & Rockland & Full & Education \\
\hline Mirror & Female & 92 & Rockland & Full & Education \\
\hline Lincoln & Female & 90 & Synergy & Associate & Psychology \\
\hline Balcony & Male & 90 & Rockland & Associate & English \\
\hline Minor & Male & 89 & Synergy & Full & Education \\
\hline Snapshot & Male & 89 & Rockland & Full & Education \\
\hline Athens & Male & 88 & Synergy & Associate & Sports management \\
\hline Riversea & Male & 88 & Synergy & Full & Music \\
\hline Agency & Female & 88 & Rockland & Associate & History \\
\hline Momentum & Male & 87 & Synergy & Full & Mathematics \\
\hline Light & Male & 87 & Rockland & Associate & Education \\
\hline Gatekeeper & Female & 86 & Exemplary & Full & Psychology \\
\hline Holme & Female & 86 & Synergy & Full & Psychology \\
\hline Ink & Female & 85 & Exemplary & Full & Education \\
\hline Prize & Male & 84 & Exemplary & Associate & Education \\
\hline Resilience & Male & 84 & Exemplary & Full & Psychology \\
\hline Bali & Female & 84 & Synergy & Associate & Education \\
\hline
\end{tabular}




\begin{tabular}{l|l|l|l|l|l}
\hline Summer & Female & 83 & Rockland & Full & Music \\
\hline Pollination & Male & 82 & Rockland & Full & Psychology \\
\hline Confidence & Female & 81 & Exemplary & Associate & Philosophy \\
\hline Steps & Male & 81 & Rockland & Associate & Criminal justice \\
\hline Evolve & Male & 80 & Exemplary & Associate & Communication \\
\hline Opportunity & Male & 80 & Exemplary & Associate & Management \\
\hline Cuttingedge & Male & 78 & Exemplary & Full & Science \\
\hline Essential & Female & 78 & Synergy & Full & Languages \\
\hline
\end{tabular}

\section{Measurements}

The purpose of the questionnaire was to objectively select mid-career faculty who reported high levels of vitality. The questionnaire comprised 37 questions, which included those designed to capture faculty demographics, and the constructs that provided the basis of the vitality score. These constructs consisted of challenge seeking, creativity, curiosity, energy, grit, motivation, open-mindedness, optimism, and risk taking. See Table 3 for a partial list of questions regarding these constructs. On each question, faculty could rate themselves on a scale from 0 to 4 . For each respondent, productivity was measured by taking the sum of professional memberships, conference attendance, presentations, journal articles, chapters, books, grants and community engagement experiences over a two-year period.

Table 3. Sample of Faculty Survey Questions and the Attitudinal Dispositions and Psychological States They Were Meant to Capture

\begin{tabular}{l|l|l}
\hline No. & Survey Item & $\begin{array}{l}\text { Attitudinal disposition / } \\
\text { psychological state }\end{array}$ \\
\hline 9 & I look on the bright side of things. & Optimism \\
\hline 10 & I learn more from failure than I learn from success. & Growth mindset \\
\hline 11 & Hard work is the key ingredient to success. & Grit \\
\hline 12 & My teaching informs my publications and research. & $\begin{array}{l}\text { Integrated scholar (outcome of } \\
\text { vitality) }\end{array}$ \\
\hline 13 & I find some part or parts of my work exciting. & $\begin{array}{l}\text { Energy } \\
\text { Curiosity to learn }\end{array}$ \\
\hline 14 & I aim to be the best in the world at what I do. & Motivation/challenge-seeking \\
\hline 15 & Setbacks don't discourage me. & Grit \\
\hline 16 & I finish what I begin. & Grit \\
\hline 17 & I am driven to succeed. & Motivation \\
\hline 18 & I have achieved a goal that took a long time to complete. & Grit \\
\hline 19 & I am confident I can deal with unexpected events & Grit \\
\hline 20 & $\begin{array}{l}\text { If someone opposes me I can find the means and a way to get what I } \\
\text { want }\end{array}$ & Grit \\
\hline 21 & I am not afraid to take risks in my work. & Risk-taking \\
\hline 23 & I keep up with the latest innovations. & Creativity \\
\hline
\end{tabular}




\begin{tabular}{l|l|l}
\hline 24 & I feel passionate about my work & Grit \\
\hline 25 & I have more energy now than I had earlier in career. & Energy \\
\hline
\end{tabular}

Note: This table illustrates that questions in the questionnaire did not contain or suggest the term vitality, so respondents were not led to answer in a particular way to demonstrate that they were vital.

\section{Quantitative Findings: Questionnaire}

\section{Rank, Disciplines, Time as Faculty, and Time at Institution}

Of the 102 questionnaire respondents, 58 were full professors and 44 were associate professors. Twentythree faculty were in the discipline of education, 16 in the sciences, nine in psychology, six in mathematics, six in social work, five in English, five in political science, four in the arts, history, management, and music, respectively, three in anthropology, two in sociology, communication, computer, business, and philosophy, respectively, and one each was associated with criminal justice, languages, and geography. The mean total number of years of faculty work was 20.22. These faulty had remained at their respective institutions for a mean of 16.73 years.

We observed a strong relationship between community engagement activities and faculty vitality and productivity. Using two-tailed Pearson correlations to analyze responses to question \#34 ("During the past two years, have you participated in public service or outreach or service-learning, or engaged scholarship?"), we found that community engagement was not significantly correlated $(p<.05)$ with faculty rank (i.e., associate or full professors, $\mathrm{n}=102$ ). Community engagement was positively correlated with productivity $(\mathrm{p}=.024)$ and vitality scores $(\mathrm{p}=.000)$, and productivity was positively correlated with vitality scores $(\mathrm{p}=.000)$. Using these three highly inter-correlated variables, we further analyzed the high vitality sub-sample $(\mathrm{n}=30)$. Testing means using independent samples t-tests, we found that mean use of community engagement over the previous two years was 2.13 times for the 72 faculty we did not interview. For the vital sub-sample of 30, it was 2.72 -not significant at the $\mathrm{p}<.05$ level but significant at $p=.067$. As expected, the interview group, or the highly vital sample, had higher means on productivity: 12.07 compared to the productivity score of $8.0(\mathrm{p}<.001)$ for the 72 faculty we did not interview. In the vital sample $(n=30)$, community engagement was even more highly correlated with productivity $(p=.003)$. These suggestive findings led us to use a mixed-methods sequential exploratory study, which is very useful in trying to understand relationships in quantitative data by using narratives (Plano Clark \& Creswell, 2008).

\section{Qualitative Findings: Narratives}

Disciplines of the 30 faculty interviewee included communications, criminal justice, education, English, history, foreign languages, mathematics, management, music, philosophy, physical education, psychology, and the sciences. Of the 26 faculty who responded in the questionnaire that they participated in community engagement, 12 detailed these activities during their interviews. The researchers carefully reviewed the themes discussed in these faculty interviews and then matched faculty descriptions about the rationale for their projects with one or more of O'Meara's (2008) motivational factors. Table 4 details the information described by the 12 twelve faculty interviewees. 
Table 4. Community Engagement Profiles of 12 Interviewees

\begin{tabular}{|c|c|c|c|}
\hline $\begin{array}{l}\text { Faculty } \\
\text { Pseudonym }\end{array}$ & Activity & $\begin{array}{l}\text { How often was } \\
\text { community } \\
\text { engagement used } \\
\text { over 2-year } \\
\text { period? }\end{array}$ & $\begin{array}{l}\text { Motivational Factors for Engagement } \\
\text { (O'Meara, 2008) }\end{array}$ \\
\hline $\begin{array}{l}\text { Professor } \\
\text { Athens }\end{array}$ & $\begin{array}{l}\text { Sporting events to raise } \\
\text { money }\end{array}$ & 4 & $\begin{array}{l}\text { Commitment to specific social issue: } \\
\text { Poverty }\end{array}$ \\
\hline $\begin{array}{l}\text { Professor } \\
\text { Bali }\end{array}$ & $\begin{array}{l}\text { Working in homeless } \\
\text { shelters and with at-risk } \\
\text { adolescent girls }\end{array}$ & 4 & $\begin{array}{l}\text { Commitment to specific social issue: } \\
\text { Homelessness }\end{array}$ \\
\hline $\begin{array}{l}\text { Professor } \\
\text { Evolve }\end{array}$ & Work with local growers & 4 & $\begin{array}{l}\text { Commitment to specific social issue: } \\
\text { Sustainability }\end{array}$ \\
\hline $\begin{array}{l}\text { Professor } \\
\text { Mirror }\end{array}$ & $\begin{array}{l}\text { Child advocacy in the } \\
\text { state }\end{array}$ & 4 & $\begin{array}{l}\text { Commitment to specific social issue: } \\
\text { Child Welfare }\end{array}$ \\
\hline $\begin{array}{l}\text { Professor } \\
\text { Pollination }\end{array}$ & $\begin{array}{l}\text { Working with prisoners } \\
\text { who are parents }\end{array}$ & 4 & $\begin{array}{l}\text { Commitment to specific social issue: } \\
\text { Parenting in prison/peace }\end{array}$ \\
\hline Professor Visor & $\begin{array}{l}\text { Regional healthcare } \\
\text { institute }\end{array}$ & 4 & $\begin{array}{l}\text { Commitment to specific social issue: } \\
\text { Health/women's health }\end{array}$ \\
\hline $\begin{array}{l}\text { Professor } \\
\text { Holmes }\end{array}$ & $\begin{array}{l}\text { Retention of students in } \\
\text { academic difficulty }\end{array}$ & 4 & Personal professional identity \\
\hline $\begin{array}{l}\text { Professor } \\
\text { Agency }\end{array}$ & Public lectures & 4 & $\begin{array}{l}\text { Personal/Professional Identity and Institution } \\
\text { type }\end{array}$ \\
\hline $\begin{array}{l}\text { Professor } \\
\text { Homeaway }\end{array}$ & Global Literacy & 4 & $\begin{array}{l}\text { Perceived fit between discipline and } \\
\text { engagement }\end{array}$ \\
\hline $\begin{array}{l}\text { Professor } \\
\text { Confluence }\end{array}$ & Writing Institute & 4 & $\begin{array}{l}\text { Perceived fit between discipline and } \\
\text { engagement/collaborative partnerships }\end{array}$ \\
\hline $\begin{array}{l}\text { Professor } \\
\text { Summer }\end{array}$ & $\begin{array}{l}\text { Regional Cultural } \\
\text { Institute }\end{array}$ & $\begin{array}{l}\text { No response on } \\
\text { questionnaire }\end{array}$ & Collaborative partnerships \\
\hline $\begin{array}{l}\text { Professor } \\
\text { Lincoln }\end{array}$ & $\begin{array}{l}\text { Autistic children } \\
\text { and their families }\end{array}$ & 4 & Facilitate student learning and growth \\
\hline
\end{tabular}

Motivation Grounded in Personal Commitments to Specific Social Issues, People, and Place Six faculty appeared to be deeply committed to changing society by addressing one of the following issues: poverty, homelessness, sustainability, child advocacy, prisoner education, and women's health.

\section{Poverty.}

I think it would be hard to be engaged in something if you're not passionate about it. -Professor Athens 
Professor Athens organized and participated in day-long sporting events to end the cycle of poverty. These widely advertised events were held on and off campus and at nearby grammar schools and junior high schools, and often drew participants of all ages. Professor Athens, an associate professor who at the time of study had taught at Synergy State for 10 years, focuses on service and service-learning more than writing and publication. He has earned extensive acknowledgment from the university administration and recognition by the public for his community work. He is intrinsically motivated by competition and challenges, many of which he creates for himself, and the need for change. He possesses a strong desire to make the world a better place for his children and their generation.

\section{Homelessness.}

So I think I am very passionate about what I teach. I kind of live it and breath it. I'm able to take it out of the four walls of academia and bring it to real people.

-Professor Bali

Professor Bali focuses on healthy lifestyles, homelessness, and adolescent girls at risk. She has been a professor of health education for 17 years and has worked at Synergy State for the past nine years. She is currently an associate professor and has written three books. As she stated in her interview:

Service-learning is infused into $75 \%$ of my classes. I do a lot in the community. I live here. All of my service projects happen here. I do the service projects because I want students to experience that this ... area is ... where they are going to make a difference.

\section{Sustainability.}

What I'm interested in is figuring out how meaning is made, how people are able to get together and understand one another or quite often misunderstand one another.

-Professor Evolve

The communications program and its flexibility regarding teaching practices are part of what attracted Associate Professor Evolve to Exemplary University, where he says he is rooted and intends to remain. "It's a place where I've been able to explore what I'm interested in and to discover what I'm good at." He has worked at Exemplary University for 10 years. At the time of the study, he was creating documentaries about social issues as a way of connecting his expertise in communications with his new interests, one of which is sustainability as it relates to community-supported agriculture and local growers of vegetables and fruits. The birth of his child was a transformative experience for Professor Evolve because it created a new identity for him - that of a steward who promotes sustainability and has a passion for growing sufficient amounts of healthy food and for caring for the earth. He spoke about how he works closely with growers of local produce and those who market it, and about how he hoped to attract student interest in these areas. He said that since he is merging his personal interests with his professional work, the job feels more like a hobby to him.

Child advocacy. Professor Mirror has taught for 20 years at Rockland University, where she is a full professor of early childhood education. She is co-authoring a book about her discipline. She is also a public advocate for children and is very knowledgeable about and influential in public policy issues for children throughout her state. At the beginning of her career, she intended to remain at Rockland University for only a short time:

I've been involved in a reflective practice group for about ten years. That's a really important part of teaching for me. . . . reflecting with colleagues about that. So that helps make it compelling, too. It helps me focus on things I want to work on. 
The reflective practice group appears to be an opportunity structure that was created by and for faculty and serves to enhance teaching and learning practices. In the recent past, Professor Mirror was selected by faculty and students to receive a distinguished faculty award for teaching. The vitality components Professor Mirror said she possesses include "crazy bad work ethic, crazy good, I guess, and an overdeveloped sense of responsibility. But really intellectual curiosity. And that's where my colleagues are great, because they really spark that and keep that going." She stated that she is an optimist and that setbacks don't discourage her; her work is exciting, and she cares deeply about it.

Prison education. Professor Pollination, who taught service-learning classes with inmates at a state prison, summed up what is most important to him:

I think changing the world actually, student by student ... I have a Granddaughter and I'd like her to live in a peaceful, just, and nonviolent and low crime world....

Professor Pollination taught in college as an adjunct and then as a full-time instructor for 25 years before coming to Rockland University, where he has worked for the past 14 years. He is a full professor of psychology. He teaches year round and also teaches online courses. Professor Pollination said he chose Rockland University because it is convenient to his home, but he remains there because he is supported by faculty and administration, and he has a great deal of autonomy. On what Professor Pollination most wishes to accomplish and his philosophy of teaching, he commented:

I'd like to try to get more professors to see the connection between what they do and the world around them and helping students become more global in their perspective and having a bigger emphasis on an ethic of care.

Of his community service work, in which he sometimes involves graduate students, he said:

They make a lot of connections. I do too. I try to connect with what we're talking about to them as well, not just to their parenting. It's a very rewarding kind of thing. And when you leave ... all of them will thank me and that's pretty powerful stuff.

\section{Women's health.}

I actually love the word vitality. You don't hear it very often and to me it's kind of like the energy that you get from being.... But the vitality has to come from within. Be mindful of where you are at the present moment ... generally and I teach that.

Professor Visor was born in the area near Rockland University and returned there with her family after a national search for the right place. She intended to stay in the area for two to three years; however, she has been teaching at Rockland for 23 years in the undergraduate and graduate schools and has been a faculty member for a total of 37 years. She is a full professor. She has established an annual health institute for health care professionals - one of only two of its kind in the country - and this, she says, is one of her successes at Rockland University. She said she is extrinsically motivated by her graduate students' enthusiastic responses to her courses and intrinsically motivated to help heal people who suffer mind-body afflictions and to promote the professional growth of students as they become healthcare professionals. 


\section{Perceived Fit between the Discipline and Engagement}

It is a common struggle among people in every vocation and any relationship to quest for that which you really love and once attained to wed yourself to it.

—Chambers \& Chambers, 2000, p. xiv

There were two faculty members whose community engagement was motivated by the perceived fit between their discipline and engagement. Two distinct ways to engage people are teaching what you love in another country and teaching teachers whose work appears to have ripple effects statewide and nationally. The narratives that follow focus on literacy education the teaching of writing.

\section{Global literacy.}

My goal is to create a place that is so comfortable for students that are typically marginalized ... It's exactly the kind of culture that I've wanted to protect and inspire.

—Professor Homeaway

While teaching high school English, Professor Homeaway realized that some students had difficulty reading, and she wanted to help them overcome this problem. She returned to graduate school and obtained a master's and a doctorate in literacy education to help future students to succeed. Now, as a full professor, she has chosen to remain at Exemplary University for the past 20 years because her goals and values match those of the institution; that is, the energy within her institution and her own are synergistic. "So I feel like just a perfect fit."

Professor Homeaway directs much of her current energy in the form of service to students at risk, while at the same time training graduate assistants to act as peer tutors to undergraduate students. She has taken five trips to her service site in Africa, with the goal of increasing global literacy, and she plans to continue this work indefinitely.

\section{Disciplinary Fit Plus Collaboration as Motivational Factors}

\section{Writing institute with global outreach.}

I would say [my work] has deepened more. I'm still doing basically what I was prepared to do, but I'm doing it radically differently and in many different venues and many different ways. I think that I've found a way to do service in a way that's meaningful for me and I think takes better advantage of my talents.

—Professor Confluence

Professor Confluence came to Rockland University for a one-year faculty position, but that was nearly 20 years ago. "I was so enchanted with working here that I've been here ever since." She is a full professor of English who teaches introductory writing courses, such as English composition as well as poetry and the novel, and is a published author.

Creation of a statewide writing project built a tight-knit community of writing teachers; thus, her current students, who are teaching candidates, are likely to work with experienced classroom teachers who were Professor Confluence's former students. The project has been such a success that teachers from other countries attended the most recent annual conference that she directed. Her dream is to establish a writing project outside of the United States. She strengthened her commitment to her profession when she applied for and won a prestigious award, which paid for travel to work on writing with teachers internationally. 
I like to think that my work has helped put into schools the kinds of teachers that I would want my children to have and that I would want your children to have, and that will help to create the kinds of people that I would like to live with in this society.... and that if we can empower teachers to feel more that they are professionals, and that they are intellectuals, and help them to also feel that sense of responsibility for the community, speaking in the broadest terms, almost like the global community, there can be no more important work.

Her work is an example of what Smitter (2000) calls "the ways in which the inner life can be expressed in and through service" (p. viii).

\title{
Motivation to Facilitate Student Learning and Growth
}

\author{
I'm not clear but there's something really unusual about us here.... We're good at thinking about \\ how to grow not just a student but a person.
}

—Professor Lincoln

Professor Lincoln has been at Synergy State University for 10 years. She is an associate professor of psychology. She has successfully integrated teaching with her research and outside professional psychology practice, and being an integrated scholar was viewed by the researcher as a positive outcome of faculty vitality. She brings her students to observe her interactions with clients and also has students accompany her when working with families in her psychology practice.

I think my biggest feeling of accomplishment comes in seeing the things my students have done. I have so many students that are post-master's and some of them post-doctorate out managing organizations and making a difference in the world in ways that make me so proud. And even those that just even with a bachelor's degree have gone out and engaged in jobs that really make a difference.

\section{Motivation Grounded in Personal/Professional Identity}

Personal identity refers to one's race, gender, sexual orientation, or disability as it relates to community engagement. Some faculty have grown up in families that socialized them to render community service or community engagement. "It is what they did and who they are now" (O'Meara, 2008, p. 19). This was the case for Professor Holme, who is motivated by her personal identity that she has professionalized through her education, and she seeks that same goal for all of her students, especially those who are struggling academically.

The idea of attending college and graduating with honors was a remote possibility for Professor Holme. She was most surprised by how much she loved learning and how, without much effort, she surpassed her own goals and expectations. Education for her and her family was a transformative experience. Part of that life-altering experience included moving far away from her home in order to take the faculty job at Synergy State, where she has worked for 11 years. Inspired by her life change, she envisioned a way to empower students. Specifically, she seeks out students who are uncertain about completing their education, and she prepares for them a home-cooked meal and convenes a social hour that has become a university tradition. As an associate professor of psychology, she is considered to be in her early mid-career but already is fulfilling the university's mission to retain diverse students. She also seems to exemplify what Chambers and Chambers (2000) refer to as the place where "service, soul, and teaching vocation [intersect]" (p. x):

When I first started, that wasn't the objective. It was just to build community, so that students of color would feel more like they belonged. And then I got to wondering, "Well, does it work? Does it do anything?" And when I collected the data, I found out like a 30\% difference [in 
retention rates].

It is little wonder that Professor Holme's mantra is, "You belong here ... and you will succeed."

\section{Motivation Grounded in a Desire for Collaboration, Relationships, Partners, and Public- Making}

When I think of work, first of all, I don't see that I come to work. I come to have fun every day. So I guess I made up my dream job.

-Professor Summer

Professor Summer came to Rockland University, she said, because the job description matched what she was seeking, but she intended to remain there for only one year. Thirty-six years later, as a late midcareer full professor, she said she enjoys her job and her students. She was determined that no one else should have to face the private dilemmas or lonely existence she faced as a musician. Her personal experience became the vision of her success. She has created and directed fine-arts camps each summer in the Rockland University area, and large numbers of students from the region converge on the camp for music and group activities that provide them with friendship and musical skills. Intrinsically, Professor Summer said she has been motivated to build a lasting community for her former students, current students, and future students, where they can come together each year. An outcome of her teaching vitality, her successful local camps serve as a model for camps in other states and regions of the country. There is an $86 \%$ return rate of students and graduates to her camp.

\section{Dual Motivations: Personal/Professional Identity along with Motivation because of Institutional Type}

Professor Agency feels a duty to educate the public about history because she works in a public comprehensive university with a clear mission. She also feels motivated and obligated to teach inside and outside of the university walls because of her love for history, her identity as a historian, and her need to share all that she discovers in her reading, research, and archival explorations. She was an adjunct professor for 22 years in this setting and has been a full-time faculty member for eight years. She makes presentations locally and regionally, and is an active member of multiple civic organizations.

My students [are most important]. I want them to love history. I don't even care if they're majoring in it. I want them to understand the value of it. I think it makes people better citizens. It makes people better people, if they can understand the past.

\section{Motivation Grounded in a Pursuit of Rigorous Scholarship and Learning}

The scholarship of engagement and intellectual discovery was not discussed in the interviews with faculty. It is likely that at public comprehensive universities the scholarship of engagement is not an essential part of the university mission as is effective teaching, student learning outcomes, and community engagement. While many faculty expressed a desire to learn and grow, none discussed his or her research or writing as rigorous scholarship in a way that fulfills the criteria of this motivational factor.

Many faculty expressed that positive changes in their work were due in part to three other factors that could be motivational in nature: good person-organization fit; being mid-career and feeling more autonomous; and possible changes in the locus of control so they could respond to intrinsic motivation more than to extrinsic motivation.

\section{Intrinsic Motivation to Create Community Engagement Opportunities}

Most institutions do not generally reward service-learning in promoting faculty or in post-tenure review (O’Meara \& Rice, 2005). Campus Compact (2013) national statistics indicate that only 68\% of their 
member institutions recognize this at all. This could be extrapolated to only about $18 \%$ of campuses nationally by assuming that the Campus Compact member institutions are more likely to reward faculty community engagement than the non-members (Campus Compact, 2013). It appears that faculty are intrinsically motivated to participate in community engagement.

\title{
Limitations of the Study
}

Seventy-two faculty respondents did not participate in face-to face interviews. The small sample of faculty (30) at three universities is not representative of all faculty at these institutions, and therefore the findings are not generalizable to all mid-career faculty or to all public comprehensive universities. Another limitation includes potential bias in asking and responding to questions. We avoided inserting any opinions, values, and beliefs into any of the interview protocols, so as to minimize reflexivity; however, questions and responses may have been influenced inadvertently by the insertion of personal issues into interview situations - a third limitation of a qualitative study (Merriam, 1998; Plano Clark \& Creswell, 2008). Also, we did not posit or test for directionality between community engagement and vitality.

\section{Significance of the Study}

\author{
So I think universities and colleges are driven by the faculty.
}

—Professor Cuttingedge

What appears to drive and sustain the long and sometimes arduous journey to the role of faculty is the pursuit of scholarly passion and the desire to become part of a dynamic and meaningful profession (O'Meara et al., 2008; Rice, Sorcinelli, \& Austin, 2000). This profession may find new meaning through community engagement activities. If the true value of faculty to the students, to the university, and to the community and beyond were better understood, higher education administrators might be persuaded to increase resources to their faculty. This study contributes to the literature on public comprehensive universities and demonstrates the values and the mission of the faculty who work there and the value of their community engagement work. In summary, vital mid-career faculty who possess good organizational fit, who share the values, mission, and goals of the university, and who are given autonomy and opportunity structures help to generate a culture that promotes community engagement that aims to intervene in societal issues and eliminate inequitable conditions.

\section{Implications of the Study}

It appears that mid-career faculty intentionally utilizes community engagement as a vehicle in the "struggle for connections and completion, service-learning and the search for personal wholeness" (Chambers \& Chambers, 2000, p. xii). However, there is a need for more qualitative studies about faculty work in a variety of institutional contexts in order to better understand the impact of community engagement on faculty. Community engagement appears to be a natural growth experience for faculty at mid-career. As Smitter (2000) notes, "service in education can transform the work as well as the lives of the faculty" (p. vii). It is possible that mid-career faculty create community engagement courses not only to improve student learning outcomes but also to help to sustain their own vitality. If community engagement does enhance faculty vitality, all faculty should be supported by their institutions to participate in community engagement. These choices may reflect Erikson's stage of generativity, which asks the question, "What will survive of me?" (Cooper, 2000, p.156). According to Ward (2010), community engagement is "bringing the work of and at the margins of the institution into its center" 
(p.119). Similarly, in a symbolic manner, it appears that faculty derive and are sustained by personal meaning from their community engagement.

\section{Author Note}

Anne M. DeFelippo, School of Nursing, Salem State University; Dwight E. Giles, Jr., College of Education and Human Development, University of Massachusetts, Boston.

\section{Correspondence}

Correspondence regarding this article should be addressed to Anne M. DeFelippo, Associate Professor, School of Nursing, Salem State University, Harrington Building, Room 214, 352 Lafayette Street, Salem, MA 01970. Phone: (978) 542-6654. E-mail: adefelippo@salemstate.edu

\section{References}

Astin, A., \& Volgelgesang, L. (2006). Understanding the effects of service-learning: A study of students and faculty. Los Angeles: Higher Education Research Institute, University of California. Retrieved from http://www.heri.ucla.edu/PDFs/pubs/reports/UnderstandingTheEffectsOfServiceLearning_FinalR eport.pdf

Baldwin, R. G., \& Blackburn, R. T. (1981). The academic career as a developmental process: Implications for higher education. Journal of Higher Education, 52(6), 598-614.

Baldwin, R. G., \& Chang, D. (2006). Reinforcing our keystone faculty: Strategies to support faculty in the middle years of academic life. Liberal Education, 92(4), 28-35.

Baldwin, R. G., DeZure, D., Shaw, A., \& Moretto, K. (2008). Mapping the terrain of mid-career faculty at a research university: Implications for faculty and academic leaders. Change Magazine, 9, 47-54.

Baldwin, R. G., Lunceford, C. J., \& Vanderlinden, K. E. (2005). Faculty in the middle years: Illuminating an overlooked phase of academic life. Review of Higher Education, 29(1), 97-118.

Blackburn, R. T., \& Lawrence, J. H. (1995). Faculty at work: Motivation, expectation, satisfaction. Baltimore: Johns Hopkins University Press.

Bringle, R. G., \& Hatcher, J. A. (2009). Innovative practices in service-learning and curricular engagement. In L. Sandmann, A. Jaeger, \& C. Thornton (Eds.), New directions for higher education (pp. 37-46). San Francisco: Jossey-Bass.

Campus Compact. (2013). Creating a culture of assessment: 2012 Campus Compact annual member survey. Boston, MA: Author. Retrieved from http://www.compact.org/wpcontent/uploads/2013/04/Campus-Compact-2012-Statistics.pdf

Campus Compact. (2014). Campus Compact annual membership survey. Retrieved from http://www.compact.org/about/statistics/2014

Carnegie Community Engagement Classification. (2015). Retrieved from http://nerche.org/index.php?option $=$ com content $\&$ view $=$ article $\&$ id $=341 \&$ Itemid $=601$

Chambers, L., \& Chambers, T. (2000). Introduction. In D. Cooper (Ed.), Trying the ties that bind: Essays on service-learning and moral life of faculty. Lansing, MI: Fetzer Institute, Michigan Campus Compact.

Cooper, D. (Ed.). (2000). Trying the ties that bind: Essays on service-learning and moral life of faculty. Lansing, MI: Fetzer Institute, Michigan Campus Compact.

Creswell, J. W., Plano Clark, V. L., Gutmann, M. L., \& Hanson, W. E. (2003). Advanced mixed methods research designs. In A. Tashakkori \& C. Teddlie (Eds.), Handbook of mixed methods in social and behavioral research (pp. 209-240). Thousand Oaks, CA: Sage. 
Dalbey, M. (1995). What is a comprehensive university, and do I want to work here? ADE Bulletin, 111. Retrieved from https://www.mla.org/bulletin_111014

DeFelippo, A. M. (2014). Prime time in the academy: The individual and institutional factors that sustain mid-career faculty vitality (Unpublished doctoral dissertation). University of Massachusetts, Boston.

Eyler, J., \& Giles, D. E., Jr. (1999). Where's the learning in service-learning? San Francisco, CA: JosseyBass.

Giles, D. E., Jr. (2008). Understanding an emerging field of scholarship: Toward a research agenda for engaged, public scholarship. Journal of Higher Education Outreach and Engagement, 12(2), 97 106.

Giles, D., Sandmann, L., \& Saltmarsh, J. (2010). Engagement and the Carnegie classification system. In H. Fitzgerald, C. Burack, \& S. Seifer (Eds.), Handbook of engaged scholarship: Contemporary landscapes, future directions. Vol. 2: Community-campus partnerships. East Lansing, MI: Michigan State University Press.

Hart, J. (2009). Creating faculty activism and grassroots leadership: An open letter to aspiring activists. In A. Kezar (Ed.), Rethinking leadership in complex, multicultural, and global environment (pp. 169-184). Sterling, VA: Stylus.

Henderson, B. B. (2007). Teaching at the people's university: An introduction to the state comprehensive university. Hoboken, NJ: Wiley.

Levine, M. L. (2000). Through Grand Canyon and Eastern Europe to habits of the heart. In D. Cooper (Ed.), Trying the ties that bind: Essays on service-learning and moral life of faculty. Lansing, MI: Fetzer Institute, Michigan Campus Compact.

Licata, C., \& Morreale, J. (Eds.). (2006). Post-tenure faculty review and renewal III. Outcomes and impact. Bolton, MA: Anker Publishing Company.

Lindholm, J. (2003). Perceived organizational fit: Nurturing the minds, hearts, and personal ambitions of university faculty. Review of Higher Education, 27(1) 125-149.

Merriam, S. B. (1998). Case study research in education. San Francisco: Jossey-Bass.

Noel, J., \& Earwicker, D. (2014). Gathering data and documenting impact: 2010 Carnegie community engagement classification application approaches and outcomes (Working paper). Boston, MA: New England Resource Center for Higher Education.

O'Meara, K. (2008). Motivation for faculty community engagement: Learning from exemplars. Journal of Higher Education Outreach and Engagement, 12(1), 7-29.

O’Meara, K., \& Rice, R. E. (2005). Faculty priorities reconsidered: Rewarding multiple forms of scholarship. San Francisco: Jossey-Bass.

O’Meara, K., \& Niehaus, E. (2009). Service-learning is... How faculty explain their practice. Michigan Journal of Community Service-Learning, 16(1), 17-32.

O’Meara, K., Terosky, A. L., \& Neumann, A. (2008). Faculty careers and work lives: A professional growth perspective. ASHE Higher Education Report, 34(3), 1-221.

O’Meara, K., Sandmann, L., Saltmarsh, J., Giles, D., Jr. (2011). Studying the professional lives and work of faculty involved in community engagement. Innovative Higher Education, 36, 83-96.

Plano Clark, V. L., \& Creswell, J. W. (2008). The mixed methods reader. Thousand Oaks, CA: Sage.

Rice, E., Sorcinelli, M. D., \& Austin, A. (2006). Heeding new voices: Academic careers for a new generation. New Pathways working paper series. No. 7. Washington, DC: American Association for Higher Education.

Saltmarsh, J., Giles, D. E., Jr., O’Meara, K., Sandmann, L., Ward, E., \& Buglione, S. (2009). Community engagement and institutional culture in higher education: An investigation of faculty reward policies at engaged campuses. Greenwich, CT: Information Age Publishing.

Saltmarsh, J., Giles, D. E., Jr., Ward, E., \& Buglione, S. (2009). Rewarding community-engaged scholarship. In L. Sandmann, A. Jaeger, \& C. Thornton (Eds.), New directions for higher education (pp. 25-35). San Francisco: Jossey-Bass. 
Smitter, A. (2000). Foreword. In D. Cooper (Ed.), Trying the ties that bind: Essays on service-learning and moral life of faculty. Lansing, MI: Fetzer Institute, Michigan Campus Compact.

Stanton, T. K., Giles, D. E., Jr., \& Cruz, N. I. (1999). Service-learning: A movement's pioneers reflect on its origins, practice, and future. San Francisco: Jossey-Bass.

Steinberg, K., Hatcher, J., \& Bringle, R. (2011). Civic minded graduate: A north star. Michigan Journal of Community Service Learning, 18(1), 19-33.

Strait, J. R., \& Lima, M. (2009). The future of service-learning: New solutions for sustaining and improving practice. Sterling, VA: Stylus.

Sykes, C. (1988). Profscam. New York: St. Martin's Press.

Ward, E. (2010). Women's ways of engagement: Exploration of gender, the scholarship of engagement and faculty roles and rewards (Doctoral dissertation). University of Massachusetts, Boston.

Ward, E., Buglione, S., Giles, D., \& Saltmarsh, J. (2011). The Carnegie classification for community engagement: Helping create the "new normal" in American higher education. In P. Benneworth (Ed.), University engagement with socially excluded communities towards the idea of "the engaged university" (pp. 285-308). New York: Springer Publishing Company. 